Sakarya Üniversitesi İlahiyat Fakültesi Dergisi

Journal of Sakarya University Faculty of Theology

ISSN: 2146-9806 | e-ISSN: 1304-6535

Cilt/Volume: 23, Say1/Issue: 44, Y1l/Year: 2021 (Aralık/December)

\title{
Müşâkele Sanatının Kavramsallaşma Sürecinde Fahreddin er-Râzî
}

Fakhr al-Dīn al-Rāzī in The Conceptualization Process of al-Mushākala (Verbal Similarity)

\begin{abstract}
Mehdi Cengiz
Dr., Artvin Çoruh Üniversitesi, İlahiyat Fakültesi, Arap Dili ve Belagatı Ana Bilim Dalı - Dr., University of Artvin Çoruh, Faculty of Theology, Department of Arabic Language and Rhetoric
\end{abstract}

mehdicengiz@artvin.edu.tr https://orcid.org/0000-0001-7593-1801

\section{Makale Bilgisi - Article Information}

Makale Türü/Article Type: Araştırma Makalesi/ Research Article

Geliş Tarihi/Date Received: 21/08/2021

Kabul Tarihi/Date Accepted: 29/11/2021

Yayın Tarihi/Date Published: 15/12/2021

Atıf/Citation: Cengiz, Mehdi. “Müşâkele Sanatının Kavramsallaşma Sürecinde Fahreddin er-Râzî”. Sakarya Üniversitesi İlahiyat Fakültesi Dergisi 23/44 (2021), 397-419. https://doi.org/10.17335/sakaifd.985761.

İntihal: Bu makale, iThenticate yazılımı ile taranmış ve intihal tespit edilmemiştir. Plagiarism: This article has been scanned by iThenticate and no plagiarism detected.

Copyright (c) Published by Sakarya Üniversitesi İlahiyat Fakültesi - Sakarya University Faculty of Theology, Sakarya/Turkey. 


\title{
Müşâkele Sanatının Kavramsallaşma Sürecinde Fahreddin er-Râzî
}

\section{Öz}

Kelâm, felsefe ve fıkıh usûlü alanında yazdığı eserlerle tanınan, 12. yüzyıl düşünürlerinden Fahreddin er-Râzî (ö. 606/1210) beyân, meâni ve bedî ilimlerinden oluşan belâgat disiplini hakkında Nihâyetü'l-îcâz fí dirâyeti'l-i câz adını verdiği bir eser kaleme almıştır. Edebi incelikten dolayı bir lafzın, aynı ifadede başka bir anlamda tekrar edilmesi olarak tanımlanan müşâkeleye, bu kitapta yer vermeyen Râzî, Mefâtîhü'l-ġayb adlı tefsirinde bu sanatı yoğun olarak kullanmıştır. Fakat müşâkele, onun döneminde henüz terimleşmediğinden bu sanatı farklı isimlerle zikretmiş, hatta yer yer ilgili âyetleri tefsir ederken açıklama yapmayıp daha önce zikredilen başka bir âyete gönderme yapmakla iktifa etmiştir. Râzî́nin, müşâkele hakkındaki düşünceleri tam olarak tespit edilmediğinden konu ile ilgili ifadeleri yanlış anlaşılmıştır. Bu nedenle Râzî'nin, müşâkele sanatı hakkında dağınık halde zikrettiği cüzî malzemelerden külıî hükümlerin çıkarılması çalışmamızın konusunu oluşturmaktadır. Bu doğrultuda makalenin girişinde müşâkele sanatının kavramsal çerçevesine yer verilecek, birinci bölümde Râzî́ye göre müşâkele sanatının mahiyeti; ikinci bölümde ise bu sanatın ona göre mecaz mı yoksa hakikat mi olduğu tartışılacaktır.

Anahtar Kelimeler: Arap Dili ve Belâgatı, Felsefe, Sekkâkî, Nihâyetü'l-îcâz, Bedî‘, Müşâkele.

\section{Fakhr al-Dīn al-Rāzī in the Conceptualization Process of al-Mushākala (Verbal Similarity)}

\begin{abstract}
Fakhr al-Dīn al-Rāzī (d. 606/1210), one of the $12^{\text {th }}$ century thinkers, who is known for his works in the field of al-kalām (Islamic theology), philosophy and figh (Islamic jurisprudence), wrote a work called Nihāyat al-ījāz fi dirāyat al-i'jāz on the 'ilm al belāgha (science of eloquence) consisting of the sciences of 'ilm al-bayān (the science of clarity of language), 'ilm al-ma'āni (the science of meanings) and 'ilm al-badī' (the science of ornamentation). al-Rāzī, who did not include the art of al-Mushākala (lexical simulation), which is defined as stating a word (lafz) by the form of another (word) in that book, used this art extensively in his tafsìr called Mefātīhu'l-gayb. However, since al-Mushākala was not yet termed in his time, he mentioned this art with different names. In fact, he did not explain while interpreting the verses and referred to another verse mentioned before. Since al-Rāzī's thoughts about al-Mushākala could not be determined exactly and his statements were misunderstood, the subject of our study is the extraction of general rule from the small materials that al-Rāzì mentions about the art of al-Mushākala. In this direction, the conceptual framework of the art of al-Mushākala will be included in the introduction of the article. In the first part, the nature of the art of al-Mushākala according to al-Rāzi will be explained, and in the second part, it will be discussed whether this art is a metaphor or a reality for him.

[You may find an extended abstract of this article after the bibliography.]

Keywords: Arabic Language and Rhetoric, Philosophy, al-Sakkākī, Nihāyat al-Ījāz, 'İlm al-Badī', al-Mushākala.
\end{abstract}

\section{Giriş}

Müşâkele sanatı hakkında bir hayli akademik çalışma yapılmıştır. Bunların bir bölümü Çifçi'nin Kemalpaşazâde'ye Göre Müşâkele Sanatı (Problemler ve Eleştiriler ${ }^{1}$ adlı makalesi gibi bir âlim özelinde mezkûr sanatı incelerken bir kısmı

1 Mehmet Faruk Çifçi, "Kemalpaşazâde'ye Göre Müşâkele Sanatı (Problemler ve Eleştiriler)”, Hitit Üniversitesi İlahiyat Fakültesi Dergisi 19/1 (2020), 119-150. 
Eliaçık'ın Bazı Belâgat Kitaplarında Müşâkele Sanatı² isimli eseri gibi müstakil olarak bu sanatı tartışır. Diğer bazıları ise Zehiyye Seryârî'nin Belâğatu'lMüşâkele ve Delâletuhâ fi'l-Kurâni'l-Kerîm'i ${ }^{3}$ ve Selahattin Yilmaz'in Kur'an'da Müşâkele Sanatı ${ }^{4}$ adlı yüksek lisans tezleri gibi müşâkele sanatının uygulaması hakkında kaleme alınmıştır. Ayrıca Avnullah Enes Ateş'in Bir Tercüme Problemi Olarak Kur'an'da Müşâkele Üslubu ${ }^{5}$ ve Ziyad Anwar Mahmood'un the Translation of al-Mushākala (Verbal Similarity) in the Prophetic Hadith into English: Problems and Strategies ${ }^{6}$ adlı makaleleri müşâkelenin diğer dillere tercümesi ile ilgili olup Yusuf b. Muhammed es-Saîd'in Dirâse akdiyye li ba ḍi'ș-ṣlfâtilletî yudde â ennehâ min bâbi'l-müşâkele' si $^{7}$ ise bu söz sanatının akaid ile ilişkisi hakkında kaleme alınmıştır. Hilal ise Râzî’ye göre müşâkele sanatını tanıtmak yerine, sadece birkaç örnek vermekle yetindiği Fahreddîn er-Râzî belâgiyyen adlı çalışmayı yapmıştır. ${ }^{8}$ Tespitlerimize göre müşâkele hakkında hazırlanan bahse konu akademik çıktıların, Râzî'nin bu söz sanatı hakkındaki fikriyatını yeterince ortaya koyamadıkları düşünüldüğünden elinizdeki bu çalışma ile belâgat tarihi açısından önemli bir boşluğun doldurulması amaçlanmıştır.

\section{Kavramsal Çerçeve}

Sözlükte "iki şeyin birbirine benzeyip uyuşması" anlamına gelen müşâkele, belâgat terimi olarak "bir lafzın, farklı anlamlarda tekrar edilmesi", daha dakik bir ifadeyle "bir mananın, kendi lafzı dışında, tahkîken ya da takdîren daha önce geçen başka bir kelimeyle ifade edilmesi"9 şeklinde tarif edilebilir. Bu sanata, dersi dinlemeyip gülen bir öğrenciye hocasının "Gül bakalım! Ben de sınavları okuduğumda güleceğim" sözü, örnek verilebilir. Hocanın sözünde geçen gülmenin gerçek olmayıp öğrencinin gülmesinin karşılığı olduğu açıkça anlaşılmaktadır. Bu örnekte de görüldüğü üzere iki lafızdan birinin gerçek anlamında kullanılmadığı müşâkelede üç unsur vardır:

2 Muhittin Eliaçı, "Bazı Belâgat Kitaplarında Müşâkele Sanatının Tanım ve Tasnifi", Kırıkkale Üniversitesi Sosyal Bilimler Dergisi 3/2 (2013), 6-15.

3 Zehiyye Seryârî, Belâğatu'l-Müşâkele ve Delâletuhâ fi'l-Kurâni'l-Kerîm (Tilimsân: Câmi'atu Ebî Bekr Balkâyad, Yüksek Lisans Tezi, 2008).

4 Selahattin Yılmaz, Kur'an'da Müşâkele Sanatı (Erzurum: Atatürk Üniversitesi, Sosyal Bilimler Enstitüsü, Yüksek Lisans Tezi, 2012).

5 Avnullah Enes Ateş, “Bir Tercüme Problemi Olarak Kur'an'da Müşâkele Üslubu”, Hitit Üniversitesi İlahiyat Fakültesi Dergisi 16/31 (2017), 109-128.

6 Ziyad Anwar Mahmood, "The Translation of al-Mushākala (Verbal Similarity) in The Prophetic Hadith Into English: Problems and Strategies", Iraqi Journal of Social Sciences 1/2 (2020), 3-14.

7 Yusuf b. Muhammed es-Saîd, “Dirâse 'akdiyye li ba'ḍi'ṣ-șıfâtilletî yudde'â ennehâ min bâbi'lmüşâkele", Mecelletu Câmiati'l-İmâm 32 (1421/2000), 15-85.

8 Mahir Mehdi Hilal, Fahreddîn er-Râzî belâgiyyen (Bağdat: Dârül-Ḥürriyye liț-Tibâa, 1397/1977).

9 Hुatîb el-Ḳazvînî, Telhîsu'l-Miftâh (Karaçi: Mektebetü'l-Büşrâ, 1431/2010), 116. 
a) müşâkel, b) müşâkil ve c) 'alâka. Genellikle daha önce zikredilen ve gerçek anlamıyla kullanılan lafza müşâkel; şekil yönüyle müşâkele benzemekle birlikte anlamı ondan farklı olan diğer kelimeye müşâkil; iki lafız arasındaki şekilsel benzerlik ilişkisine ise alâka denir. ${ }^{10}$ Yukarıda zikredilen örnekte öğrencinin gülmesi müşâkel, şekil yönünden ona benzeyen kelime (güleceğim) ise müşâkildir. Alâka ise iki kelimenin zihindeki musâhabet(birliktelik)idir.

Müşâkele sanatı takdirî ve tahkikî olmak üzere ikiye ayrılır. Müşâkel ve müşâkilin ifadede açıkça zikredildiği müşâkeleye "müşâkele-i tahkîkiyye" adı verilirken sadece müşâkil bulunup ona eşlik eden müşâkelin açıkça zikredilmediği türe "müşâkele-i takdîriyye" denir. ${ }^{11}$ Tahkîkî müşâkeleye "Şüphesiz onlar bir tuzak kurarlar, ben de tuzak kurarım." 12 âyeti örnek verilebilir. Bu ifadede müşâkel olan يَكِيدُونَ lafzı zikredilmiş ve arkasından müşâkil yani وَأَكِيدُ sözü kullanılmıştır. Mütenebbî’nin (ö. 354/965), Seyfüddevle el-Hamdânî’yi (ö. 356/967) överken söylediği aşağıdaki beyit ise müşâkele-i takdîriyyeye örnek olarak zikredilebilir. [et-Tavîl]

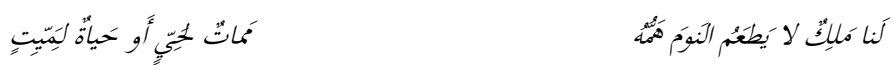

Bizim hükümdarımız uykuyu tatmaz; onun gayreti diri için ölüm, ölü için de hayattır. ${ }^{13}$

Bu beyitte şair, Seyfüddevle'nin uyumamasını yemek yememeye benzetir. Müşebbehun bihin (yemek) zikredilmediği bu benzetmede (istiâre), uykuyu tatmaz lafzı müşâkil (benzeyen ikinci lafız) olup bunun müşâkeli (ilk lafız) lafzen söylenmeyen يَطْعَمُ الطَََّامَ (yemek yer) sözüdür. Müşâkil bulunup müşâkel bulunmadığından bu beyitte, müşâkele-i takdîriyye vardır. Aynı şekilde hurma fidanı dikerken valiyi gören bir fakirin ona hitaben söylediği aşağıdaki beyitler de takdiri müşâkeleye örnek verilebilir. [el-Kâmil]:

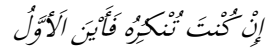

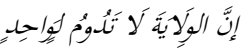

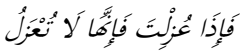

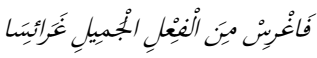

Hiç kimsenin valiliği sürekli değil, bunu kabul etmezsen, [bak bakalım] öncekiler nerede! Sen, güzel fiillerden fidan dik! Sen [görevden] azledilsen de, onlar azledilmez! ${ }^{14}$

Bu beyitlerde fidan diken valinin güzel işler yapması, müşâkele yoluyla fidan dikme eylemi kullanılarak (فَاغْرِنْ) ifade edilmiştir.

10 Adem Yerinde, "Belagat İlminde Müşâkele Sanatı", Usul İslam Araştırmaları 30/30 (2018), 18.

11 bk. İbn Ma'sûm, Envâru'r-Reb̂i, 5/285.

12 et-Târık 86/15-16.

13 Ebü't-Ṭayyib Ahmed b. Hüseyin el-Mütenebbî, Dîvânu Ebi't-Tayyib el-Mütenebbî (Beyrut: Dâru Beyrût, 1403/1983), 379.

14 es-Seyyid Ali Sadruddîn b. Ma'sûm el-Medenî İbn Ma'sûm, Envâru'r-Rebî 'fî Envâ i'l-Bedî́; thk. Şakir Hâdî Şükr (Necef: Matba'atu'n-Nu'mân, 1389/1969), 5/286. 
Müşâkelenin unsurlarından olan müşâkil, hakikî anlamında kullanılmad1ğından genellikle mecaz ile karıştırılır. Bu ikisi arasındaki fark, müşâkelenin tanımında geçen "başka bir kelimeyle ifade edilmesi (musâhabet)" kaydıyla açıklanabilir. Yani mecazda bir söz, hakikî anlamının dışında kullanılırken müşâkelede bir kelime, başka bir kelimenin yerine kullanılmaktadır. Dolay1sıyla mecaz bir anlam yerine farklı bir anlamı; müşâkele ise bir lafız yerine başka bir lafzı irade etmektir. İradenin peşi sıra mütekellim bir lafzı, bir manaya tayin eder ki bu işleme isti'mâl adı verilir. Buna göre müşâkele bir manada kullanılan lafzı, bu anlamda kullanılmayan başka bir kelime ile değiştirmektir. ${ }^{15}$ Söz gelimi "Onlar tuzak kurdular" sözünün arkasından zikredilen "Allah da tuzak kurdu" ifadesindeki "Tuzak kurdu" fiilinde "Tuzaklarina karşılık verdi" sözü mecaz değil, müşâkeledir. Çünkü “Tuzak kurdu” lafzı, “Tuzaklarına karşılık verdi” lafzının yerinde kullanılmıştır.

Yukarıdaki örneklerde görüldüğü üzere müşâkelede ikinci lafız, birincisine mana açısından değil, şekil yönünden benzer. Fakat bu lafzî benzeyişin etkisi, anlamsal benzeyişten daha fazla olmadığından müşâkele sanatı, anlamı güzelleştiren sanatlar [el-muhassinâtü'l-ma'neviyye] arasında sayılmıştir. ${ }^{16}$

\section{Râzî̀'ye Göre Müşâkele Sanatı}

Râzî'nin müşâkele sanatının terimleşmesindeki rolünün tespit edilebilmesi için Râzî öncesinde bu söz sanatının geçirdiği değişimler ve zamanla bu sanata hangi adların verildiği belirlenmelidir. Edebî bir sanat olarak müşâkele sanatından bahseden ilk kişinin Ferrâ (ö. 207/822) olduğu söylenir. ${ }^{17}$ O, müşâkele ismi yerine "cezâ/ karşılık" (الجزاء) lafzını kullanır. ${ }^{18}$ Hicri 3. yüzyıl dil âlimlerinden İbn Kuteybe (ö. 276/889) ise müşâkele ile ilgili âyetleri "Anlamları farklı olduğu halde, bir fiilin karşılığının (çok daha vurgulu ve güçlü şekilde) aynı cümlede yine kendi lafzıyla ifadesini bulması"

15 Ebü'l-Hayr '̇sâmüddîn Taşköprüzade Ahmed Efendi, Şerhu Fevâidi'l-Ġyâsiyye min 'Ilmeyi'l-meânî ve'l-beyân (Dersaâdet: Dârü't-Tibâ'ati'l-Âmire, 1312/1895), 272. Ayrıca bk. Yüksel Çelik, Es-Seyyid eş-Şerîf el-Cürcânî'nin «el-Misbâh fî Şerh el-Miftâh» adlı eserinin tahkik ve tahlili edisyon kritik (İstanbul: Marmara Üniversitesi, Sosyal Bilimler Enstitüsü, Doktora Tezi, 2009), [Tahkik kısmı] 729-730; Çifçi, “Kemalpaşazâde'ye Göre Müşâkele Sanatı”, 126.

16 Nitekim Sekkâkî gibi klasik dönem yazarları müşâkele sanatını el-muhassinâtü'l-ma'neviyye arasında değerlendirmiştir. Bk. Ebû Yakûb Yusuf b. Muhammed es-Sekkâkî, Miftâhu'l-ulûm, thk. Abdulhamîd Hindâvî (Beyrut: Dâru'l-Kütübi'l-İlmiyye, 1435/2014), 533.

17 İsmail Durmuş, "Müşâkele”, Türkiye Diyanet Vakfi İslâm Ansiklopedisi (Ankara: TDV Yayınları, 2006), 32/154.

18 Ebû Zekeriyyâ Yahyâ b. Ziyad el-Ferrâ, Meâni'l-Kurr'ân, thk. Ahmed Yusuf en-Necâtî vd. (M1sır: Dârü'l-Mıșriyye li't-Te'lîf ve't-Terceme, ts.), 1/117. 


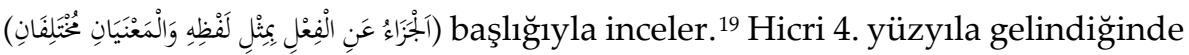
Rummânî (ö. 384/994), müşâkeleyi "aynı kökten türemiş kelimelerin bir araya gelmesi" olarak tarif ettiği "tecânüs"ün alt başlı̆̆ı olan müzâvece terimim ile adlandırır. ${ }^{20}$ Hicri 5. asır dilcilerinden Hatîb et-Tebrîzî (ö. 502/1109) ise müşâkeleyi "şairin, şekilleri aynı, anlamları farklı olan kelimeleri, aynı beyitte farklı manalarda bir araya getirmesi" olarak tanımlar. ${ }^{21}$ Tespitlerimize göre bu farklı isimlendirmelerden sonra ilk defa Zemahşerî (ö. 538/1144), müşâkeleyi, bedî̀ disiplininde işlendiği şekliyle edebî bir sanat olarak kullanmış ${ }^{22}$ ve yer yer bu sanata mukâbele demiştir. ${ }^{23}$

Zemahşerî'nin tefsirinde yer verdiği belâgat uygulamalarını dikkate alan ve Abdülkāhir el-Cürcânî'nin (ö. 471/1078-79) Delâilü'l-icâz'1 ile Esrârü'lbelâğa'sının yanısıra Râzî'nin Nihâyetü'l-îcâz'ından da yararlanan Sekkâkî, Miftâhu'l-ulûm'un meânî, beyân ve bedî‘ disiplinlerini kapsayan üçüncü bölümünü yazmıştır. Sekkâkî'nin bu eseri ile müşâkele sanatı kavramsal çerçevesini kazanmış ve sonraki dönemlerde çoğunlukla müşâkele adıyla anılmıştır. Müşâkelenin, Râzî’nin isteği doğrultusunda Miftâhu'l-ulûm'u yazan Sekkâkî'nin ${ }^{24}$ elinde kavramsallaşıp sistemleştiği düşünüldüğünde bu sanatın farklı isimlerle anılması yani edebî bir sanat olarak yeni yeni oluşmaya başlaması ile müşâkelenin terimleşmesi arasında Râzî'nin köprü vazifesi gördüğü söylenebilir. Bu yüzden Râzî’ye göre müşâkelenin mahiyetini ve özelliklerini tespit etmek, bahsi geçen sanatın geçirdiği tarihsel değişimi göstermek açısından önem arz eder.

Ne var ki Râzî, belâgat ilimlerine dair kaleme aldığ1 Nihâyetü'l-îcâz adlı eserinde müşâkeleye yer vermemiş ve farklı kitaplarında bu sanatı ifade etmek için muhtelif isimler kullanmıştır. Bu nedenle müşâkelenin tanımı, k1sımları ve özellikleri, Râzî'nin, Kurân-1 Kerîm âyetlerini anlamak için belâgat sanatlarını yoğun olarak kullandığı Mefâtîhu'l-gayb isimli tefsirindeki dağınık ve cüzî malumattan elde edilebilir.

19 Ebû Muhammed Abdullah b. Müslim İbn Ḳuteybe, Tevîlu müşkili'l-Kur'ân, thk. İbrahim Şemsüddîn (Beyrut: Dârü'l-Kütübi'l-İlmiyye, ts.), 171.

20 Ebü'l-Hasan Ali b. İsa el-Bağdâdî er-Rummânî, en-Nüket fi i câzi'l-Ḳur'an ( Selâs u resâil fî i câzi'lKur'ân li'r-Rummânî ve'l-Hatțâbî̀ ve Abdülkâhir el-Cürcânî içinde), thk. Muhammed Halefullah - Muhammed Zağlûl Sellâm (Kahire: Dârü'l-Meârif, 1395/1976), 99.

21 Ebû Zekeriyyâ el-Hatîb Yahyâ b. Ali et-Tebrizi, Kitâbü'l-kâfi fi'l-arûd ve'l-kavâfì, thk. elHassânî Hasan Abdullah (Kahire: Mektebetü'l-Hancî, 1415/1994), 199-200.

22 Yerinde, "Belagat İlminde Müşâkele Sanatı", 14; Durmuş, "Müşâkele", 32/155.

23 Muhammed Ebû Musa, el-Belâğatü'l-Kur'âniyye fî tefsiri'z-Zemahşserî ve es serühâ fi'd-dirâsâti'lbelâğiyye (Kahire: Mektebetu Vehbe, 1408/1988), 577.

24 Musa Alak, “Fahreddin er-Râzî'nin Nihâyetü'l-Îcâz Adlı Eserinde Abdülkahir el-Cürcânı̂'ye İtiraz Ettiği Meseleler", Şarkiyat Mecmuası 18 (2011), 17. 
Râzî̀ye göre aşağıdaki âyetlerde Allah (c.c.), kâfirlerin alaylarına

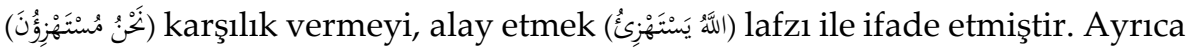
bu iki âyeti tefsir ederken müşâkele sanatının yaygınlığını göstermesi açısından pek çok âyet ve hadisi de zikretmiştir.

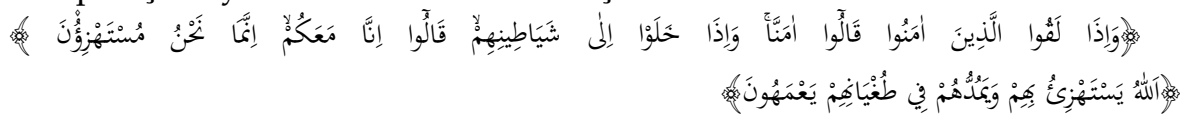

"İman edenlerle karşılaşınca "inandık" derler, şeytanlarıyla baş başa kaldıklarında ise "Biz sizinleyiz, biz yalnızca alay etmekteyiz" derler. Asıl onlarla alay eden ve azıp saparak dolaşmalarına izin veren Allah'tır." 25

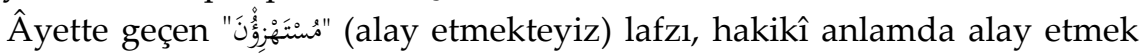

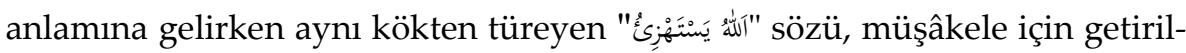
miş olup "Allah, onların alaylarına karşılık verdi." manasındadır. Râzî bu âyeti tefsir ederken müşâkele yerine, "bir şeyin karşılığının o şeyin adıyla isimlendirilmesi" ${ }^{26}$ sözünü kullanır ve benzer bir durumun eş-Şûrâ 42/40, elBakara 2/194, en-Nisâ 4/142, Âli İmrân 3/54 âyetleri ve aşağıdaki hadisler için de geçerli olduğunu belirtir. ${ }^{27}$ Râzî'nin mezkûr sözle müşâkele sanatını kastedip etmediğini anlamak için ilgili naslar incelenmelidir. Söz konusu hadislerin ilki kendini hicveden birisi hakkında Hz. Peygamberin söylediği şu sözdür:

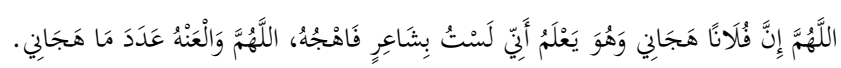

"Allah'ım falanca kişi beni hicvetti. Ve o biliyor ki ben şair değilim. Onu hicvet, Allah'ım onun hicivleri sayısınca ona lanet et." 28

Bu hadiste zikredilen هَجَانِي "hicvetti” kelimesi hakikî anlamda, akabindeki “فَاهُجُهُ "onu hicvet" ise birincil anlamıla değil mecazî manada "onun hicvine karşılık ver" şeklinde kullanılmış olup her ikisi de aynı kökten türemiştir.

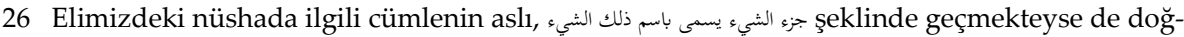
rusu جزاء الشيء يسمى باسم ذلك الشيء olmalıdır. Çünkü bu nüshaya göre anlam “Bir şeyin cüz'ü o şeyin ismiyle isimlendirilebilir" şeklindedir. Fakat Râzî'nin bahsettiği konu, bir şeyin cüzü ile o şeyi isimlendirmek değil, bir şeyin karşlığının o şeyin adıyla anılmasıdır. Nitekim Râzî'nin bu kullanıma örnek olarak zikrettiği yukarıdaki âyet ve hadisler "bir şeyin karşllığının o şeyin adıyla isimlendirilmesi" ile ilgilidir.

27 Ebû Abdillâh (Ebü'l-Faḍl) Muhammed b. Ömer Fahreddin er-Râzî, Mefâtîhü'l-ġayb (etTefsîrü'l-kebîr) (Beyrut: Dâru İhyâi't-Turâsi'l-'Arabî, 1420/1999), 2/309.

28 Rûyânî'nin Müsned'inde bu kişinin Amr b. Âs olduğu rivayet edilmektedir. Ebû Bekr Muhammed b. Harun Rûyânî, Müsnedü'r-Rûyânî ve bi zeylihi'l-müstedrek mine'n-nușûsi's-sâkıta, thk. Eymen Ali Ebû Yemânî (Kahire: Müessesetu Kurtuba, 1416/1995), 257. Ayrıca bk. Ebû Cafer Ahmed b. Muhammed b. Selâme et-Tahâvî, Şerhu Müşkili'l-âsar, thk. Şuayb el-Arnaût, (Beyrut: Müessesetü'r-Risâle, 1415/199), 8/441; Ebû Şücâ' Şînuye b. Şehredar b. Şîrûye ed-Deylemî, el-Firdevs bi me'sûri'l-hitâb, thk. Saîd b. Besyûnî Zaglûl, (Beyrut: Dârü'l-Kütübi'l-'illmiyye, 1406/1986), 1/506. 
Râzî'nin bu hadisteki ifadeyi "bir şeyin karşılı̆̆ının, o şeyin adıyla isimlendirilmesi" şeklinde tavsif etmesi ile İbn Kuteybe'nin bahsi geçen hadisi "anlamları farklı olmakla beraber aynı lafızla fiilin karşılığını zikretmek"

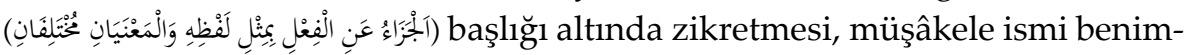
senmeden önce karşılık "الجزاء" ifadesinin yaygın kullanıldığını göstermesi bakımından önemlidir. ${ }^{29}$

Râzî'nin "bir şeyin karşılığının o şeyin adıyla isimlendirilmesi” şeklinde yaptığ1 tavsife örnek olarak zikrettiği ikinci hadis ise şöyledir:

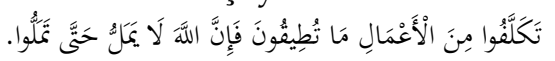

"Amellerden gücünüz yettiği kadarını yüklenin. Zira siz bıkmadıkça, Allah (c.c.) da bikmaz." 30

Yukarıdaki ifadede ise ikinci fiil حَتَّى تَكَُُّ (siz bikana kadar) hakikî anlamında kullanılmış iken birincisi Allah (c.c.) bıkıp usanmayacağı için “amellere karşılık olarak sevap vermeyi terk etmez" manasındadır. Çünkü bıkmak fiili bir şeyi istedikten sonra yüksünüp ağır görmek anlamında olduğundan Tanrı'nın ulûhiyyeti ile bağdaşmayıp kulların vasıflarındandır. ${ }^{31}$ Nitekim muhaddis âlimler yukarıda zikredilen hadisi şerh ederken benzer açıklamalara yer vermiştir. ${ }^{32} \mathrm{Bu}$ bağlamda temsil gücünün yüksek olması ve Râzî ile benzer açıklamalarından dolayı Bedrüddin el-'Aynî’nin (ö. 855/1451) sözlerine yer verilecektir. 'Aynî, bu hadiste müşâkele ve izdivâc sanatının olduğunu söyleyip bu edebî sanatı "manaları farklı olsa da iki lafızdan birinin diğerine muvafık olmasıdır" şeklinde tanımlar. Peşi sıra aynı durumun, eş-Şûrâ 42/40, el-Bakara 2/194 âyetlerinde de geçerli olduğunu öne sürer. Zikredilen âyetlere ilişkin Râzî ve 'Aynî'nin ifadeleri arasındaki benzerlik, her iki âlimin dile getirdiği sanatın aynı olduğunu göstermesi bakımından kayda değerdir. ${ }^{33}$

29 İbn Kuteybe, Tevîlu müşkili'l-Kur'ân, 171.

30 Ebû Abdillâh Muhammed b. İsmail el-Buhârî, el-Câmi u'ṣ-șahịh, thk. Muhammed Züheyr b. Nâsır en-Nâsır (Dâru Țavkì'n-Necât, 1422/2001), "Kitâbu'l-1̂mân", 31 (No. 43); Ebü'l-Hüseyin el-Kuşeyrî Müslim b. el-Haccâc, el-Müsnedü'ș-șahîhhu'l-muhtașar bi nakli'l-adli ani'l-ádli ilâ Rasûlillâh sallallâhu aleyhi ve sellem, thk. Muhammed Fuâd Abdülbâkî (Beyrut: Dâru İhyai'tTürâsi'll-'Arabî, ts.), "Kitâbu șalâti'l-müsâfirîn ve ḳașruhâ", 30.

31 Ebû Muhammed Bedreddin Mahmud b. Ahmed 'Aynî, Umdetü'l-ḳârî şerḥi Sahîhịi'l-Buhââr (Beyrut: Dâru İhyai't-Türâsi'l-'Arabî, ts.), 1/257.

32 Zeynüddin Muhammed Abdürrauf b. Tacilarifin b. Ali el-Münâvî, Feyḍül-kadîr şerhii'lCâmii's-sag̀îr (Beyrut: Dârü'l-Ma'rife, 1391/1972), 4/354; Ebü'l-Hasan Ubeydullah b. Muhammed Abdüsselam el-Mübârekfûrî, Mir'âtü'l-mefâtiḥ şerḥu Mişkâti'l-mesâbiḥ (Bombay: elCâmiatü's-Selefiyye, 1405/1985), 4/241; Ebû Abdillâh Muhammed b. Ali b. Muhammed eşŞevkânî, Neylü'l-evțâr şerhi Münteka'l-ahbâr (Kahire: Mustafa el-Bâbî el-Halebî, ts. ), 3/222. 'Aynî, Umdetü'l-kârî, 1/257. 
Râzî, Şûrâ sûresi 40. âyette geçen Allah'ın alay etmesi ifadesini açıklarken “bir şeyin karşılığının, o şeyin adıyla isimlendirilmesi” şeklinde yaptığı izaha örnek olarak aşağıdaki âyeti zikreder.

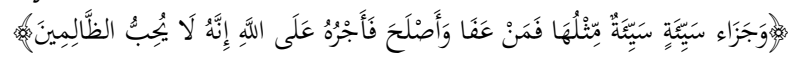

“Bir kötülüğün karşılığ1, onun gibi bir kötülüktür (ona denk bir cezadır). Ama kim affeder ve arayı düzeltirse, onun mükâfatı Allah'a aittir. Şüphesiz O, zâlimleri sevmez." 34

Râzî, yukarıdaki âyeti açıklarken öncelikle "Seyyie (kötülük)’e karşılık vermeğe izin verilip meşru olduğu halde neden buna seyyie denilmiştir?" sorusunu gündeme getirir ve Zemahşerî'nin bu soruyu şöyle cevapladığını söyler:

Âyette zikredilen birinci fiil ve bunun cezası/karşıllğı seyyiedir. Çünkü bu, başına böyle bir şey gelen kimseye zarar verir. Allah (c.c.) şöyle der: “Onlara bir seyyie/kötülük dokunduğunda bunlar sendendir derler" burada kastedilen onların başına gelen musibet ve beladır. ${ }^{35}$

Zemahşerî'nin bu sözlerinin ardından başka bir cevap olarak şunu da nakleder: "Mecaz yoluyla bir fiil, diğerinin mukabilinde kullanılınca diğerinin ismi buna verildi." Bu iki görüş arasında tercih yapan Râzî, Zemahşerî'nin sözlerini daha doğru bulur. ${ }^{36}$ Tîbî (ö. 743/1343) ise Zemahşerî'nin bu ayeti

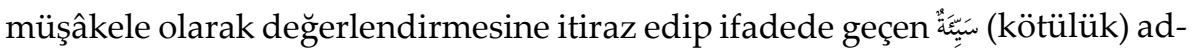

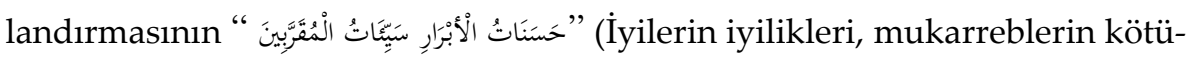
lüğüdür) gibi olduğunu, yani onların affetmek yerine karşılık vermelerinin kötülük olarak nitelendirildiğini söyler. ${ }^{37}$

Râzî'nin, müşâkele sanatını "bir şeyin karşılığının, o şeyin adıyla isimlendirilmesi" şeklinde zikrettiği "bir diğer âyet de el-Bakara 2/194'tür:

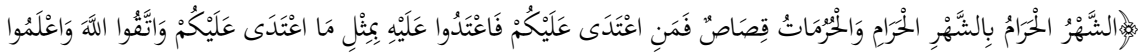

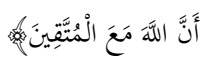

"Haram ay, haram aya karşılıktır. Hürmetler (dokunulmazlıklar) karşılıklıdır. (O hâlde) kim size saldırırsa, size saldırdığı kadar siz de ona saldırın. Allah'a karşı gelmekten sakının ve bilin ki, Allah takva sahipleriyledir." 38

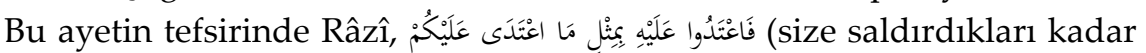
siz de onlara saldırın) cümlesinin takdirinin "Kim size karşı haddini aşarsa onlara mukabele edin." şeklinde olduğunu; haddi aşanlara mukabele etmenin düşmanlık olarak isimlendirilmesinin sebebinin ise daha önce zikredildiğini

34 eş-Şûrâ $42 / 40$.

35 Ebü'l-Kâsım Cârullah Mahmud b. Ömer ez-Zemahşerî, el-Keşşâf an hạâaikki ġavâmiḍi't-tenzîl ve uyûni'l-ekâavil fî vucûhi't-tevîll (Beyrut: Dârü'l-Kitâbi'l-'Arabî, 1407/1987), 4/229.

36 Fahreddin er-Râzî, Mefâtîhü̈l-ġayb, 27/604-605.

37 Fahreddin er-Râzî, Mefâtị̂ü̈l-ġayb, 14/76-77.

38 el-Bakara 2/194. 
söyler. ${ }^{39}$ Râzî̀nin daha önce geçtiği diyerek işaret ettiği açıklama aşağıdaki âyette geçen عُدْوَانَ (düşmanlık) lafzıyla alakalıdır.

$$
\text { 罗 }
$$

"Fitne kalmayıncaya ve din yalnız Allah'ın oluncaya kadar onlarla savaşın. Onlar savaşmaya son verecek olurlarsa, düşmanlık yalnız zalimlere karşıdır." 40

Râzî, yukarıdaki ayetin "Düşmanlık yalnız zalimlere karşıdır" kısmını açıklarken "hak ve doğru olduğu halde neden savaşa düşmanlık ismi verilmiştir?" diye bir soru sorulursa, savaşın, kâfirlerin düşmanlığının cezası olduğunu, bu sebeple de buna, düşmanlık isminin verilebileceğini söyleyip bu bağlamda eş-Şûrâ 42/40, el-Bakara 2/194, Âli İmrân 3/54 ve et-Tevbe 9/79 âyetlerini de bu kullanıma misal olarak zikreder. ${ }^{41}$

Râzî'nin Allah'ın alay etmesi sözünü açıklarken "bir şeyin karşılığının, o şeyin adıyla isimlendirilmesi"ne örnek verdiği en-Nisâ 4/142. âyet şöyledir:

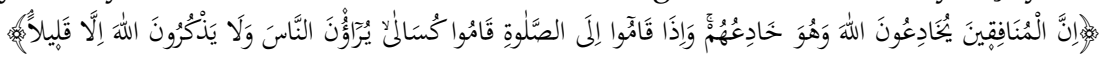

“Gerçek şu ki, münafıklar (sözde), Allah'ı aldatmaktadırlar. Oysa O, onları aldatandır. Namaza kalktıkları zaman, isteksizce kalkarlar. İnsanlara gösteriş yaparlar ve Allah'1 ancak çok az anarlar." 42

Yukarıdaki âyeti yorumlarken müşâkele sanatına dair hiçbir şey zikretmeyen Râzî, müşâkili yani وَهُو خَادِعُهُمْ ifadesini “onların tuzaklarına azapla karşıllı verecektir" şeklinde açıklar.

Râzî'nin “bir şeyin karşılığının, o şeyin adıyla isimlendirilmesi"ne verdiği son örnek ise Âli İmrân sûresinin aşağıdaki âyetidir:

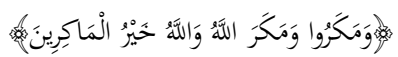

“Onlar tuzak kurdular. Allah da tuzak kurdu. Allah, tuzak kuranların en hayırlısıdır." 43

Râzî yukarıda geçen ifadeyi yorumlarken mekr (tuzak kurmak)in, şerri karşı tarafa ulaştırmak için hile yapmaktan ibaret olduğunu, bunun ise Allah (c.c.) hakkında muhal olduğunu söyler. Dolayısıyla da ona göre tuzak lafzının Allah (c.c.) için kullanımı müteşâbihâttandır. Bu durum ikinci tuzak kurma (مَ) fiilinin gerçek anlamda olmadı̆̆ını ve mezkûr âyette Râzî̀ye göre "bir şeyin karşılığının, o şeyin adıyla isimlendirilmesi" yani müşakele sanatının var olduğunu gösterir. Bu ayetin yorumuna kelâmî bir problem olarak yaklaşan Râzî, buradaki muhtemel üç anlamı zikreder. Bunlardan birincisi tuzak

39 Fahreddin er-Râzî, Mefâtîhü'l-g்ayb, 5/293.

40 el-Bakara 2/193.

41 Fahreddin er-Râzî, Mefâtîhü'l-g்ayb, 5/292.

42 en-Nisâ 4/142.

43 Âl-i İmrân 3/54. 
kurmanın cezasının, tuzak kurmakla ifade edilmesidir. Bu duruma "Kötülüğün karşılığı onun misli ile kötülüktür." 44 âyetini örnek veren Râzî, benzer şekilde kandırmanın cezasının kandırma; alay etmenin karşılı̆̆ının ise alay olarak isimlendirildiğini söyler. ${ }^{45}$

Râzî'nin Allah'ın alay etmesini açıklarken zikrettiği eş-Şûrâ 42/40, el-Bakara 2/194, en-Nisâ 4/142, Âli İmrân 3/54 âyetleri incelendiğinde ilgili fiillerin karşılıklarının aynı eylemlerle adlandırıldığı görülmektedir. Fakat Râzî, bu âyetlerin hiçbirini açıklarken müşâkele terimini kullanmamış, bunun yerine "bir şeyin karşılığının, o şeyin adıyla isimlendirilmesi” şeklinde açıklamayı tercih etmiştir. Ayrıca onun örnek olarak yer verdiği Bakara sûresi 194. âyette, konunun geçtiği eş-Şûrâ 42/40, el-Bakara 2/194, Âli İmrân 3/54, et-Tevbe 9/79 âyetlerine atıf yapmaktadır. et-Tevbe 9/79'un dışındaki âyetlerin açıklaması geride geçtiğinden yalnızca mezkûr âyet değerlendirilecektir.

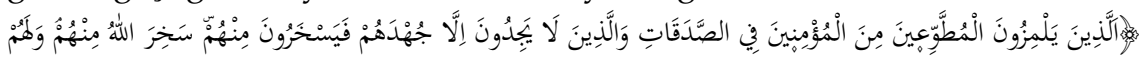

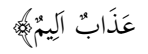

"İnananlardan, istekleriyle ve farz edilenden fazla tasadduk edenlerle ve güçleri neye yetiyorsa ancak o kadar verenlerle alay edip onları ayıplayanları Allah, bu hareketlerinin karşılığı olarak cezalandırır ve onlar için elemli bir azap var." 46

Râzî bu âyette geçen سَخِرَ اللهُ مِنْهُمْ "Allah onlarla alay etti” ifadesini tefsir ederken "sen bu konuda kuralı öğrendin" der ve herhangi bir açıklama yapmaz. ${ }^{47} \mathrm{Bu}$ kuralın ne olduğuna ise aşağıdaki hadiste geçen "Rabbiniz hoşnut olur." ifadesini yorumlarken yer verir.

$$
\text { وَعَجِبَ رَبْكُمْمْ مِنْ شَابِّ لَيَسَتْ لَهُ صَبْوَةٌ }
$$

"Yoldan çıkmamış gençten Allah hoşnut olur." 48

Allah'ın hoşnutluğunun Âdemoğullarınınkinden farklı olduğunu söyleyen Râzî; el-Enfâl 8/39, et-Tevbe 9/79 ve en-Nisâ 4/142 âyetlerini zikreder ve bu âyetlerde Allah'a nispet edilen tuzak kurma ve alay etmenin kullarınkinden farklı olduğunu dile getirir Akabinde ise ilgili konu hakkındaki kuralı şöyle açıklar:

Bu tür lafızlar arazların başlangıcına değil, nihâyetine hamledilir. Burada da durum böyledir. Bir şeyden şaşıran, onu büyük görür. Allah hakkında taaccüp, Allah'ın bu durumu büyük göreceği anlamına hamledilir. Bu hal kötü ise büyük bir azap, iyi ise büyük sevaplar vardır. ${ }^{49}$

44 eş-Şûrâ $42 / 40$.

45 Fahreddin er-Râzî, Mefâtîhü'l-g்ayb, 8/236.

46 et-Tevbe $9 / 79$.

47 Fahreddin er-Râzî, Mefâtîḥül-ġayb, 16/111.

48 Ebü't-Tahir Mecdüddin Muhammed b. Yakub b. Muhammed el-Fîrûzâbâdî, Beșâiru zevi'ttemyîz fì lețâifi'l-Kitâbi'l- 'azîz, thk. Ali en-Neccâr (Beyrut: el-Mektebetü'l-İlmiyye, ts.), 4/20.

49 Fahreddin er-Râzî, Mefâtîh ü̉'l-ġayb, 26/324. 
Görüldüğü gibi Râzî'nin zikrettiği bu kural belâğat disiplini yani müşâkele ile ilgili değil, Allah'a izafe edilen sıfatların tevîli ile alakalıdır. Yani alay etmek ifadesi Allah'a nispet edildiğinde bu kelimenin hakikî anlaminda kullanılmadığı dolayısıyla da tevil edilmesi gerektiği anlaşılmaktadır.

Râzî̀nin âyetlere yaptı̆̆ı göndermeler çerçevesinde “Bir şeyin karşılığının, o şeyin adıyla isimlendirilmesi"ne dair yukarıda naklettiğimiz örnekler incelendiğinde bunların tahkîkî müşâkele ile yani müşâkil ve müşâkelin beraber bulunduğu cümleler ile alakalı olduğu görülmektedir. Buradan hareketle Râzî'nin takdîri müşâkeleyi tefsirinde kullanmadığı düşünülmemelidir. Çünkü Râzî, aşağıdaki âyette geçen Allah'ın boyası ifadesini yorumlarken müşâkelenin bu kısmı hakkında açıklama yapmıştır.

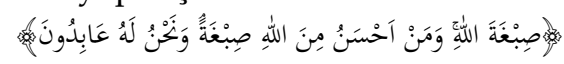

"Allah'ın boyasıyla boyandık. Boyaca O'ndan daha güzel olan kim vardır? Biz yalnız O'na kulluk ederiz." 50

Râzî yukarıdaki âyette geçen "Allah'ın boyası" ifadesi ile ne kastedildiği konusunda farklı görüşler öne sürüldüğünü fakat bunlardan en güzelinin "Allah'ın dini" manasının murat edilmesi olduğunu söyler. Allah'ın dininin neden boya ile ifade edildiği konusunda ise aralarında tercih yapmadan 4 vecih zikreder. Bunlardan birincisi şöyledir: Boya lafzının, din için kullanımının sebebi müşâkele tarikidir. ${ }^{51} \mathrm{Bu}$ durum, ağaç diken ve senin de onun şerefli olmasını emretmek istediğin birisine -her zaman şerefli olan birisini kastederek- söylediğin şu söz gibidir: "Falancanın diktiği gibi sen de dik." (اغرس كما يغرس فلان) Bu cümlede zikredilen müşâkele, 'dik' sözü ile 'diken kişinin eylemi' arasındadır. Çünkü "Falanca gibi dik." demek "Onun gibi iyilik yap." anlamına gelir. Eğer ortada bir eylem olarak dikmek olmasaydı bu söz yerinde olmazd1. ${ }^{52} \mathrm{Bu}$ örnekte yalnızca müşâkele lafzı (dik) bulunup ona eşlik eden müşâkel (şerefli olmak) zikredilmediği için müşâkele-i takdîriyye vardır. Yukarıdaki örneği her ne kadar ismini zikretmese de Zemahşerî'nin el-Keşşâf indan alan Râzî; el-Bakara 2/15, en-Nisâ 4/142, Âli İmrân 3/54, eş-Şûrâ 42/40 ve Hûd 11/38 âyetlerinin de yukarıdaki gibi olduğunu söyler. ${ }^{53}$

Râzî'nin bu örnekte müşâkele sanatının ismini açıkça zikredip bu durumun daha önce açıkladı̆̆ımız el-Bakara 2/15, en-Nisâ 4/142, Âli İmrân 3/54,

50 el-Bakara 2/138.

51 Rivayet edildiğine göre Hristiyanlar çocuklarını vaftiz ederken sarı renkli bir suya batırırlarmiş. Mezkûr âyette bu olaya işaret edilerek (boya) manasındaki صِنغَ kelimesi kullanılmıştır. Bk. Fahreddin er-Râzî, Mefâtîhü'l-ġayb, 4/75.

52 Şerefüddin Hüseyin b. Muhammed et-Ṭ̂̂b̂̀, Fütûhü'l-g்ayb fi'l-keşf an ḳınâi'r-reyb, thk. İyâd Muhammed Ġavc - Cemil Benî 'Atâ (Dübey: Câizetu Dübey ed-Devliyye li'l-Kurr'âni'l-Kerîm, 1434/2013), 3/122.

53 Fahreddin er-Râzî, Mefâtîhü'l-g்ayb, 4/75. 
eş-Şûrâ 42/40 ayetlerinde de geçerli olduğunu söylemesi, Onun "Bir şeyin karşılığının, o şeyin adıyla isimlendirilmesi" sözüyle müşâkeleyi kastettiğini ve bu sözün sadece tahkiki müşâkeleyi içermediğini göstermektedir. Râzî́nin örnek olarak zikrettiği Hûd 11/38 âyet ise şöyledir:

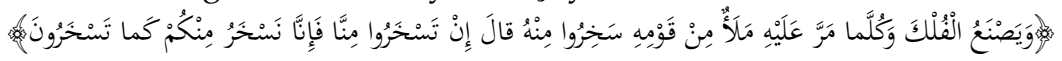

“Gemiyi yapıyor, kavminin ileri gelenleri kendisine her uğradıklarından onunla alay ediyorlardı. Dedi ki: Eğer bizimle alay ediyorsanız iyi bilin ki alay ettiğiniz gibi biz de sizinle alay edeceğiz." 54

Râzî "Suhriyyet/alay etme günah izlerindendir. O halde bu, bir peygambere nasıl uygun olur?" sorusuna tek seçenek olarak şöyle cevap verir: "Allah (c.c.) "Bir kötülüŭün karşılığı, onun gibi bir kötülüktür" 55 ayetinde olduğu gibi buradaki mukabeleyi suhriyyet olarak isimlendirmiştir." 56 Râzî'nin bu sözleri ile sonraki dönem müfessirlerinin açıklamaları arasındaki benzerlik dikkat çekmektedir. Söz gelimi Hâzin'in (ö. 741/1341) aşağıdaki yorumu Râzî'nin bahsi geçen açıklaması ile örtüştüğü gibi Râzî'nin mezkûr sözlerinin müşâkele sanatıyla alakalı olduğunu göstermesi açısından da kayda değerdir.

Eğer suhriyyet/alay etmek, peygamberlik makamına yakışmaz; o halde nasıl Hz. Nuh, bizimle alay ediyorsanız iyi bilin ki alay ettiğiniz gibi biz de sizinle alay edeceğiz demiştir, dersen; ben derim ki: Bu fiil (ikincisi suhriyyet) "Bir kötülüğün karşılığı, onun gibi bir kötülüktür" 57 âyetinde olduğu gibi izdivaç yoluyla cümlede müşâkele için kullanılmıştır. ${ }^{58}$

Görüldüğü üzere Hâzin peygamberlik makamına alay etmenin yakışmayacağı gerekçesiyle ayeti tevil etmekte ve bu tevili yaparken de Râzı̂’nin örnek olarak verdiği Şûrâ sûresi 40. âyetini kullanmakta ve bu sanatı izdivaç yoluyla müşâkele olarak nitelendirmektedir.

Müşâkele sanatının tahkîkî ve takdîrî olarak iki kısmını da tefsirinde inceleyen ve "bir şeyin karşılığının, o şeyin adıyla isimlendirilmesi" ifadesi ile müşâkeleyi kastettiği anlaşılan Râzî’ye göre müşâkele sanatının mecaz mı yoksa hakikat mı olduğunun tespiti, bedî‘ sanatlarından olan müşâkelenin beyan disipliniyle ilişkisini göstermesi açısından önem arz etmektedir.

\section{Râzî́ye Göre Müşakele Mecaz mı Yoksa Hakikat mi?}

Müşâkele sanatının mecaz mı yoksa hakikat mı olduğu belâğat âlimlerince tartışılmıştır. Nitekim Teftâzânî (ö. 792/1390), Sekkâkî'nin Miftâhu'l-ulûm adlı

54 Hûd 11/38.

55 eş-Şûrâ 42/40.

56 Fahreddin er-Râzî, Mefâtîhü'l-g்ayb, 17/346.

57 eş-Şûrâ 42/40.

58 Alaeddin Ali b. Muhammed el-Bağdâdî el-Hुâzin, Lübâbü't-te'vîl fî̀ meâni't-tenzîl (Beyrut: Darü'l-Kütübi'l-İlmiyye, 1415/1995), 2/484. 
eserine yazdiğı haşiyede bu sanatın ne hakikat ne de -muteber bir mecaz alakası bulunmadığı için- mecaz olduğunu söylemiştir. Dolayısıyla müşâkelenin, mecaz ve hakikatin dişında başka bir kullanım ya da müsâhabet alâkası bulunan mecaz olduğunu iddia etmiştir. ${ }^{59}$ Siyalkûtî (ö. 1067/1657) ise Teftâzânî'nin el-Mutavvel'ine yazdığı haşiyede müşâkelenin mecaz olduğu iddiası ile bu sanatın muhassinâtı-bedîiiyyeden sayılması arasında çelişki olduğunu ifade etmiştir. Bu doğrultuda Siyalkûtî mecaz ile müşâkele arasındaki ilişkiyi lafızları elbiseye benzeterek açıklamıştır. Buna göre müşâkele sanatında mâna bir elbiseden başka bir elbiseye nakledilirken mecazda lafız bir mânadan başka bir mânaya intikal etmektedir. ${ }^{60}$ Kemalpaşazâde ise müşâkeleyi bir tür mecaz olarak kabul etmiştir. ${ }^{61}$ Müşâkelenin bir kısmının mecaz-1 mürsel, bir kısmının ise istiare kapsamında değerlendirildiği de ifade edilmiştir. ${ }^{62}$ Kendisinde mecaz ilgisi açık olmayan müşâkele örnekleri müsâhabet (beraberinde bulunma) alakasından dolayı bazı belâğat âlimlerince mecaz-1 mürsel olarak kabul edilmişse de bu konuda edebiyat çevrelerinin ortak bir kabulünden bahsetmek mümkün görünmemektedir. Hatta bu bağlamda İbn Yakûb el-Mağribî, müşâkelenin ne hakikat ne de mecaz olduğunu öne sürmüştür. ${ }^{63}$

Müşâkele sanatına farklı isimlerle yer veren Râzî'nin konuyla alakalı zikrettiği aşağıdaki örnekler incelendiğinde ona göre bu sanatın mecaz ya da hakikat olmasıyla ilgili iki farklı yaklaşım sergilediği göze çarpmaktadır.

\subsection{Râzî’nin Müşâkeleyi Mecaz ile İlişkilendirmesi}

Râzî tefsirinin pek çok yerinde müşâkele sanatını mecaz olarak değerlendirir. Bunlardan birincisi, aşağıdaki âyette zikredilen haram kelimesinin vacip anlamında kullanılmasıyla alakalıdır.

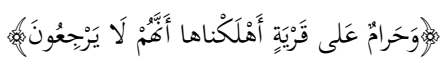

"Helak ettiğimiz bir şehir halkının, dönüp bizim katımıza gelmemesine imkân yok." 64

Râzî, yukarıdaki âyette geçen harâm lafzının vacip anlamına gelmesinin delilinin âyet, istimâl ve şiir olduğunu söyledikten sonra isti'mâlin delili ola-

59 Sa'düddîn et- Teftâzânî, Şerḥu'l-kısmi's s-sâlis min Miftâhi'l-ulūm lil-'Allâma et-Teftâzânî (Cambridge: Houghton Library, Harvard University), 214b. https://curiosity.lib.harvard.edu/islamic-heritage-project/catalog/40-990073453990203941 (Erişim 10 Haziran 2021).

60 Abdülhakîm b. Şemsiddîn Muhammed es-Siyalkûtî, Hâşiyetü's-Siyalkûtî alâ kitâbi'l-Mutavvel, (Kum: Menşûrâtü'r-Radî, 1404/1983), 543.

61 Çifçi, "Kemalpaşazâde' ye Göre Müşâkele Sanatı", 127.

62 Durmuş, "Müşâkele", 32/155.

63 Ebü'l-Abbas Ahmed b. Muhammed İbn Ya'kub el-Mağribi, Mevâhibü'l-fettâh fî şerhịi Telhîsi'lMiftâh (Beyrut: Dârü'l-Kütübi'l-'ilmiyye, 2003), 2/505.

64 el-Enbiya 21/95. 
rak iki zıt şeyden birinin, diğerinin adıyla isimlendirilmesinin, meşhur bir mecaz olduğunu söyler ve daha önce zikredildiği üzere Şûrâ sûresi 40. âyeti buna örnek olarak zikreder. ${ }^{65}$ el-Mahsĥl isimli fıkıh usûlü eserinde de bir şeyi zıddıyla isimlendirmeye Şûrâ sûresi 40. âyeti örnek veren Râzî, bunu mecazın alakaları arasında sayar. ${ }^{66}$ Mecazın alakası benzerlik olur ise buna istiare adı verilir. Nitekim Râzî mecazın alakaları arasında saydığı müşâbehetin, muste‘âr olarak adlandırıldığını söyler. ${ }^{67}$ Benzer şekilde Nihâyetü'l-îcaz'da da mecazın istiâreden umumi olduğunu ifade eder. ${ }^{68}$

Râzî aşağıdaki ayeti tefsir ederken neden karnı üstünde sürünmeye, yürümek ismi verildiğini anlatırken ilgili kelimede ya istiare ya da müşâkele bulunduğunu söyler.

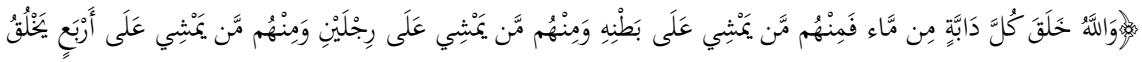

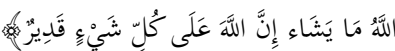

“Allah, bütün canlıları sudan yarattı. İşte bunlardan bir kısmı karnı üzerinde sürünür, kimi iki ayak üzerinde yürür, kimisi dört ayak üzerinde yürür. Allah, dilediğini yaratır. Çünkü Allah, her şeye hakkıyla gücü yetendir." 69

Râzî bu âyeti tefsir ederken neden karnı üzerine sürünmeye yürümek denildiğine dikkat çeker ve bebeklerin sürünmekle nitelendirilirken yürümekle vasıflanmadığını söyler. Bu soruya cevap olarak ise iki ihtimalden bahseder:

a. Âyette istiâre olabilir. Çünkü Araplar, devam eden iş hakkında, "iş yürüyor" derler. Benzer şekilde "Falancanın işi yürümüyor" da denilir.

b. Yahut da yürüyenlerle beraber zikredildiğinden sürünenlere de müşâkele yoluyla yürüyen denilmiştir. ${ }^{70}$

Râzî bir önceki âyeti tefsir ederken müşâkele sanatının meşhur bir mecaz olduğunu yukarıdaki âyette ise istiâre ile müşâkelenin birbirinden farklı olduğunu söyler. Buna göre mecaz-1 mürsel ile umumi anlamdaki mecazın bir parçası olan istiareyi kastetmediği, dolayısıyla müşâkelenin ona göre mecaz1 mürsel olduğunu söylemek mümkündür.

Benzer şekilde Râzî'nin aşağıdaki âyeti tefsir ederken iki mütelâzımdan birinin, diğerinin ismiyle adlandırılmasını anlatırken söyledikleri de onun müşâkeleyi mecaz kabul ettiğine örnek verilebilir.

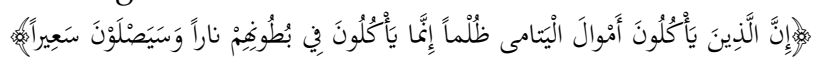

65 Fahreddin er-Râzî, Mefâtîhị̈l'-g்ayb, 22/185.

66 Ebû Abdillâh (Ebü'l-Faḍl) Muhammed b. Ömer Fahreddin er-Râzî, el-Mahșûl fì ilmi uș̂uli'lfikh, thk. Taha Cabir Feyyaz el-'Alvânî (Beyrut: Müessesetü'r-Risâle, 1412/1992), 1/325.

67 Fahreddin er-Râzî, el-Mahșûl, 1/325.

68 Ebû Abdullah Muhammed b. Mahmûd el-'Aclî el-İsfahânî, el-Kâş̧if ani'l-Mahṣ̣̂̂l fì ilmi'l-uṣ̂ul, thk. Adil Ahmet Abdülmevcûd - Ali Muhammed Mu'avvaḍ (Beyrut: Dârü'l-Kütübi'l-ìlmiyye, 1419/1998), 2/277.

69 en-Nûr 24/45.

70 Fahreddin er-Râzî, Mefâtîhü̈l-g்ayb, 24/407. 
"Yetimlerin mallarını zulümle yiyenler, ancak ateş yerler, o mallar, karınlarında ateştir adeta ve onlar, alevli ateşe atılacaklardır." 71

Yukarıdaki âyeti açıklayan Râzî, Şûrâ sûresi 40. ayette olduğu gibi iki mütelâzımdan birinin diğerinin ismiyle adlandırılmasının mecaz olduğunu öne sürer. Bu da ona göre müşakele sanatının mecaz olduğuna delalet eder. Râzî'nin, Şûrâ sûresi 40. âyetteki mecazın alakası olarak "Bir şeyin karşılığ1nın, o şeyin adıyla isimlendirilmesi" sözüyle yukarıda aynı âyeti açıklarken iki mütelâzımdan birinin diğerinin ismiyle adlandırılması sözü arasında çelişki akla gelmekteyse de bir mecazın birden fazla alakası olabilir.

\subsection{Râzî'nin Müşâkeleyi Hakikat ile İlişkilendirmesi}

Müşâkele sanatının mecaz olduğuna dair yukarıda zikredilenlerin aksine

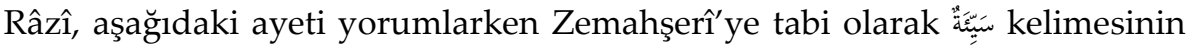
lügat anlamından yola çıkar ve bu lafzın hakikî anlamında kullanıldığını öne sürer.

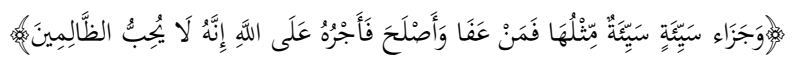

“Bir kötülüğün karşılığı, onun gibi bir kötülüktür (ona denk bir cezadır). Ama kim affeder ve arayı düzeltirse, onun mükâfatı Allah'a aittir. Şüphesiz O, zâlimleri sevmez." 72

Daha önce zikredildiği üzere Râzî "Seyyie (kötülük)'e karşılık vermeğe izin verilip meşru olduğu halde neden buna seyyie denilmiştir?" sorusuna Zemahşerî'nin kelimenin kök anlamına uygun olarak yaptığı yorum ile ya da "mecaz yoluyla biri diğerinin mukabilinde kullanılınca diğerinin ismi buna kullanıldı" diyerek cevap verilebileceğini zikredip doğru olanın Zemahşerî'nin görüşü olduğunu belirtir. ${ }^{73}$ Âlûsî (ö. 1270/1854), Zemahşerî'nin ilgili yorumunda lafzın hakikî anlamına riayet edildiğini söyler. ${ }^{74}$ Buradan hareketle Râzî'nin, müşâkeleyi hakikat olarak gördüğü söylenebilir.

\subsection{Tercih}

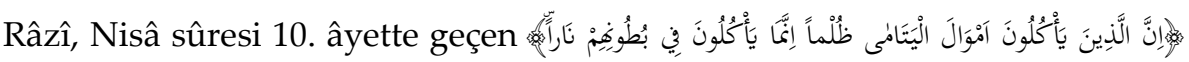
Yetimlerin mallarını haksız olarak yiyenler şüphesiz karınlarına ancak ateş dolduruyorlar." ifadesini tefsir ederken Şûrâ sûresinin 40'1ncı âyeti olan

71 en-Nisâ 4/10.

72 eş-Şûrâ 42/40.

73 Fahreddin er-Râzî, Mefâtîhü'l-ġayb, 27/604-605.

74 Ebü's-Senâ Şihâbüddîn Mahmud b. Abdillâh Âlûsî, Rûhü'l-meânîfî̀ tefsîri'l-Kur'âni'l-azîm ve'ssebi'l-meŝân̂,, thk. Ali Abdülbari Atiyye (Beyrut: Dârü'l-Kütübi'l-İlmiyye, 1415/1995), 13/47; Benzer açıklamalar için bk. İsamüddin İsmail b. Muhammed Konevi İsmail Efendi, Hâşiyetü'lKonevî alâ tefsîri'l-Beyḍ̂â̂, thk. Abdullah Ömer (Beyrut: Dârü'l-Kütübi'l-'̇lmiyye, 1422/2001), 17/254; Ahmed Hindâvî Hilâl, el-Mebâhisiü'l-beyâniyye fî tefsîri'l-Fahri'r-Râzî dirâsetun belâğiyyetun tafșîliyyetun (Kahire: Emîre li't-Tibâ'a, 1420/1999), 241. 


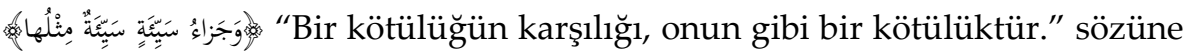
değinmiş ve bu âyetin mecaz olduğunu ${ }^{75}$ dile getirmiştir. Fakat Şûrâ sûresinde geçen yukarıdaki ifadeyi açıklarken hakikatin esas alınması gerektiğini öne sürer. ${ }^{76}$ Bunun nedeni Ahmed Hindâvî Hilâl'in de belirttiği gibi ilgili ifa-

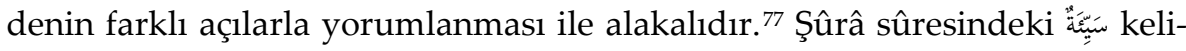
mesi, birinci fiilin karşılığı olmakla mukayyet, Râzî'nin hakikî anlamda kullanıldığını iddia ettiği Nisâ sûresindeki âyet ise mutlaktır. O halde Râzî̀ye göre aynı cümlenin bazen hakikî bazen de mecazî anlamda kullanılabildiği, bunu belirleyen şeyin ise ifadenin siyâk ve sibâkı olduğu söylenebilir.

Ahmed Hindâvî Hilâl'e göre Râzî çoğu yerde müşâkelenin mecaz olduğunu söylerken bir yerde hakikat olduğunu öne sürmüştür. Dolayısıyla da Râzî̀'ye göre bu edebî sanatı mecaz kabul etmek daha evlâdır. ${ }^{78}$ Fakat Râzî́nin

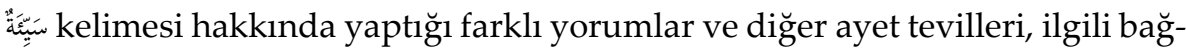
lamlarda değerlendirildiğinde onun müşâkele sanatına ne mecaz ne de hakikat dediğini bilakis bu konuda belirleyici olanın cümlenin bağlamı olduğunu

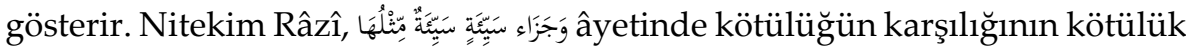
olmasını yani kötülüğün cezasının kötü kimseye nispetle kötü olmasını, kelimenin kök anlamından yola çıkarak hakikat olarak değerlendirir. İki mütelâzımdan birinin diğerinin ismiyle isimlendirilmesinin ise mecaz olduğunu söyleyip biraz önce zikrettiğimiz aynı âyeti buna örnek verir. Burada dikkat edilmesi gereken husus Şûrâ sûresi 40. âyetin hakikat ya da mecaza örnek olarak değil, müşâkeleye misal olarak zikredildiğidir. Çünkü bu âyette Karâfî'nin de dediği gibi iki vecih de caizdir.

1. İlgili lafız hakikî anlamında kullanılmıştır. Çünkü ceza suçluya zarar verir.

2. İlgili lafız mecazî anlamda kullanılmıştır. ${ }^{79}$

Tefsirinden yapılan yukarıdaki alıntıların oluşturduğu kanaate göre Râzî için önemli olan, bir ifadede beraber zikredilen lafzın mecaz, istiare ya da hakiki anlamda olması değil, birinci kelimeden farklı bir anlam taşımasıdır. O halde müşâkele aynı lafzın iki farklı anlamda bir arada kullanılmasıdır ki buna eşsesliler de dâhildir. Kısaca Râzî’ye göre müşâkelenin olduğu iki kelimeden birincisi hakikî veya mecazî manada olabileceği gibi ikincisi de birincisi ile aynı anlamda olmamak şartıyla hakikat ya da mecaz olabilir.

75 Fahreddin er-Râzî, Mefâtîhü̈l-ġayb, 9/506.

76 Fahreddin er-Râzî, Mefâtị̂hü'l-g்ayb, 27/604-605.

77 Hilâl, el-Mebâhisü'l-beyâniyye, 241.

78 Hilâl, el-Mebâhịin̈̈l-beyâniyye, 241.

79 Ebü'l-Abbâs Şihâbüddîn Ahmed b. İdrîs Karâfî, Nefâisü'l-ușûl fi şerhi'l-Mahșûl, thk. Adil Ahmed Abdülmevcûd - Ali Muhammed Mu'avvaz (Mekke: Mektebetü Nizâr Mustafa el-Bâz, 1416/1995), 2/885. 


\section{Sonuç}

Aynı ifadede, bir lafzın farklı bir anlamda kullanılıp tekrar edilmesi olarak tanımlanan müşâkeleye ve bu sanat hakkındaki bazı tartışmalara, ilk dönemlerden itibaren kaleme alınan tefsir ve dil eserlerinde yer verilmiştir. Söz gelimi İbn Kuteybe, Tanrı'da bulunması muhâl olup yaratılmışlara ait olan sıfatlar, Allah'a nispet edilirse -eğer bu yerlerde ilgili kelime farklı bir anlamda tekrar ediliyorsa- müşâkele sanatının olduğunu ifade edip bu sanatı "anlamları farklı olduğu halde bir fiilin karşılığının o fiille zikredilmesi" şeklinde açıklamıştır. Sekkâkî'nin Miftâhu'l-ulûm adlı eserini kaleme almasıyla müşâkele sistemli olarak incelenmiş ve bu sanat yaygın olarak müşâkele adıyla anılmaya başlanmıştır.

Zaman açısından müşâkelenin gelişimi ile Sekkâkî eliyle sistemleştiği dönem arasında bulunan Fahreddîn er-Râzî'nin, bu sanatın kavramsallaşmasında önemli bir yeri olduğu söylenebilir. Belâgat disiplini hakkında yazdı̆̆ Nihâyetü'l-îcâz'da müşâkeleye yer vermemesine rağmen Râzî, Mefâtîhü̈'l-g்ayb adlı tefsirinde bu sanatı farklı isimlerle zikredip özellikle kelâm konularıyla ilgili tartışmalarda yoğun olarak kullanmıştır.

Tefsirinde müşâkele sanatına genellikle “bir şeyin karşılığının o şeyin adıyla isimlendirilmesi" şeklinde yer veren Râzî, yer yer müşâkele ismini de kullanır. Müşâkeleyi tahkîkî ve takdîrî olarak iki kısımda incelemese de bu bölümlerle alakalı âyetleri tefsir ederken bu sanatı gündeme getirir. Mezkûr sanatla ilgili açıklama yaparken genellikle konu ile alakalı olan diğer âyetleri örnek veren Râzî, bu sanatın lafzî güzelliği üzerinde değil, anlamla olan yakın bağı üzerinde durur.

Müşâkele sanatının beyân disiplini ile yakın ilişkisi nedeniyle hakikat mi yoksa mecaz mı olduğu, mecaz ise mecaz-1 mürsel mi yoksa istiâre mi olduğu tartışılmıştır. Râzî bazı âyetleri yorumlarken müşâkele sanatının yaygın bir mecaz olduğunu, bazılarında ise hakikat olduğunu ifade eder. Onun konu hakkında verdiği örnekler incelendiğinde müşâkeleyi hakikat ya da mecaz olmaktan ziyade cümlenin bağlamına göre isimlendirdiği görülmektedir. 


\section{Kaynakça}

Alak, Musa. “Fahreddin er-Râzî'nin Nihâyetü'l-Îcâz Adlı Eserinde Abdülkahir elCürcânî'ye İtiraz Ettiği Meseleler". Şarkiyat Mecmuası 18 (2011), 1-17.

Âlûsî, Ebü's-Senâ Şihâbüddîn Mahmud b. Abdillâh. Rûhü'l-meânî fî tefsîri'l-Kur'âni'laẓ̂m ve's-sebi'l-meșânî. thk. Ali Abdülbari Atiyye. 16 Cilt. Beyrut: Dârü'l-Kütübi'l-İlmiyye, 1415/1995.

Ateş, Avnullah Enes. “Bir Tercüme Problemi Olarak Kur'an'da Müşâkele Üslubu”. Hitit Üniversitesi Ilahiyat Fakültesi Dergisi 16/31 (2017), 109-128.

'Aynî, Ebû Muhammed Bedreddin Mahmud b. Ahmed. Umdetü'l-ḳ̂̂rî şerḥi Saḥ̂hhi'lBuhârî. 12 Cilt. Beyrut: Dâru İhyai't-Türâsi'l-'Arabî, ts.

Buhârî, Ebû Abdillâh Muhammed b. İsmail. el-Câmi u'ș-șahîh. thk. Muhammed Züheyr b. Nâsır en-Nâsır. 9 Cilt. Beyrut: Dâru Tavḳi'n-Necât, 1422/2001.

Çelik, Yüksel. Es-Seyyid eş-Şerîf el-Cürcânî'nin «el-Misbâh fî̀ Şerh el-Miftâh» adlı eserinin tahkik ve tahlili edisyon kritik. İstanbul: Marmara Üniversitesi, Sosyal Bilimler Enstitüsü, Doktora Tezi, 2009.

Çifçi, Mehmet Faruk. “Kemalpaşazâde'ye Göre Müşâkele Sanatı (Problemler ve Eleştiriler)". Hitit Üniversitesi İlahiyat Fakültesi Dergisi 19/1 (2020), 119-150.

Deylemî, Ebû Şücâ' Şîrûye b. Şehredâr b. Şîrûye. el-Firdevs bi me'sûri'l-hitâb. thk. Saîd b. Besyûnî Zaglûl. Beyrut: Dârü'l-Kütübi'l- 'İlmiyye, 1406/1986.

Durmuş, İsmail. "Müşâkele". Türkiye Diyanet Vakfı İslâm Ansiklopedisi. 32/154-155. Ankara: TDV Yayınları, 2006.

Ebû Musa, Muhammed. el-Belâğatü'l-Kur'âniyye fî tefsiri'z-Zemahşerî ve eșerühâ fi'ddirâsâti'l-belâ̆gyyye. Kahire: Mektebetu Vehbe, 1408/1988.

Eliaçık, Muhittin. "Bazı Belâgat Kitaplarında Müşâkele Sanatının Tanım ve Tasnifi”. Kırıkkale Üniversitesi Sosyal Bilimler Dergisi 3/2 (2013), 6-15.

Fahreddin er-Râzî, Ebû Abdillâh (Ebü'l-Faḍl) Muhammed b. Ömer. el-Mahṣ̂̂ul fî ilmi uṣ̂uli'l-fikh. thk. Taha Cabir Feyyaz el-'Alvânî. Beyrut: Müessesetü'r-Risâle, 1412/1992.

Fahreddin er-Râzî, Ebû Abdillâh (Ebü'l-Faḍl) Muhammed b. Ömer. Mefâtîhü'l-ġayb (etTefsîrü'l-kebîr). Beyrut: Dâru İhyâi't'-Turâsi'l'-'Arabî, 3. Basım, 1420/1999.

Ferrâ, Ebû Zekeriyyâ Yahyâ b. Ziyad. Meâni'l-Kur'ân. thk. Ahmed Yusuf en-Necâtî vd. 3 Cilt. Mısır: Dârü'l-Mıșriyye li't-Te'lîf ve't-Terceme, ts.

Fîrûzâbâdî, Ebü't-Tahir Mecdüddin Muhammed b. Yakub b. Muhammed. Beșâiru zevi't-temyîz fî lețâifi'l-Kitâbi'l- 'azîz. thk. Ali en-Neccâr. 6 Cilt. Beyrut: el-Mektebetü'l-'̇lmiyye, ts.

Hâain, Alaeddin Ali b. Muhammed el-Bağdâdî. Lübâbü't-te'vîl fì meâni't-tenzîl. Beyrut: Darü'l-Kütübi'l-İlmiyye, 1415/1995.

Hilâl, Ahmed Hindâvî. el-Mebâhis ü̈ll-beyâniyye fî̀ tefsîri'l-Fahri'r-Râzî dirâsetun belâğiyyetun tafṣiliyyetun. Kahire: Emîre li't-Tıbâ'a, 1420/1999.

Hilal, Mahir Mehdi. Fahreddîn er-Râzî belâgìiyyen. Bağdat: Dârül-Hürriyye liṭ-Ṭibâa, 1397/1977.

İbn Ḳuteybe, Ebû Muhammed Abdullah b. Müslim. Tevîlu müşkili'l-Ḳur'ân. thk. İbrahim Şemsüddîn. Beyrut: Dârü'l-Kütübi'l-'̇lmiyye, ts. 
İbn Ma'sûm, es-Seyyid Ali Sadruddîn b. Ma'sûm el-Medenî. Envâru'r-Rebî'fî̀ Envâi'lBedî: thk. Şakir Hâdî Şükr. Necef: Matba'atu'n-Nu'mân, 1389/1969.

İbn Ya'kub el-Mağribi, Ebü'l-Abbas Ahmed b. Muhammed. Mevâhibü'l-fettâh fî şerḥi Telhîsi'l-Miftâh. 2 Cilt. Beyrut: Dârü'l-Kütübi'l-'̇lmiyye, 2003.

İsfahânî, Ebû Abdullah Muhammed b. Mahmûd el-'Aclî. el-Kâşif ani'l-Mahșûul fî ilmi'luṣ̂ul. thk. Adil Ahmet Abdülmevcûd - Ali Muhammed Mu'avvaḍ. Beyrut: Dârü'l-Kütübi'l-İlmiyye, 1419/1998.

Karâfî, Ebü'l-Abbâs Şihâbüddîn Ahmed b. İdrîs. Nefâisü'l-uṣ̂̂l fî şerḥi'l-Mahṣ̣̂̂l. thk. Adil Ahmed Abdülmevcûd - Ali Muhammed Mu'avvaz. Mekke: Mektebetü Nizâr Mustafa el-Bâz, 1416/1995.

Kazvînî, Hatîb. Telhîsu'l-Miftâh. Karaçi: Mektebetü'l-Büşrâ, 1431/2010.

Konevi İsmail Efendi, İsamüddin İsmail b. Muhammed. Hâşiyetü'l-Konevî alâ tefsîri'lBeyḍ̂âî. thk. Abdullah Ömer. Beyrut: Dârü'l-Kütübi'l-İlmiyye, 1422/2001.

Mahmood, Ziyad Anwar. "The Translation of al-Mushākala (Verbal Similarity) in The Prophetic Hadith Into English: Problems And Strategies". Iraqi Journal of Social Sciences 1/2 (2020), 3-14.

Mübârekfûrî, Ebü'l-Hasan Ubeydullah b. Muhammed Abdüsselam. Mirâtü'l-mefâtih şerḥu Mişkâti'l-mesâbiḥ. 9 Cilt. Bombay: el-Câmi 'atü's-Selefiyye, 1405/1985.

Münâvî, Zeynüddin Muhammed Abdürrauf b. Tacilarifin b. Ali. Feyḍ̈̈l-kadîr şerḥi'lCâmi 'i's-sag̀îr. 6 Cilt. 2. Baskı. Beyrut: Dârü'l-Ma rife, 1391/1972.

Müslim b. el-Haccâc, Ebü'l-Hüseyin el-Kuşeyrî. el-Müsnedü'ṣ-șahîhu'l-muhtașar bi nakli'l-ádli ani'l-ádli ilâ Rasûlillâh sallallâhu aleyhi ve sellem. thk. Muhammed Fuâd Abdülbâkî. 5 Cilt. Beyrut: Dâru İhyai't-Türâsi'l-'Arabî, ts.

Mütenebbî, Ebü't-Tayyib Ahmed b. Hüseyin. Dîvânu Ebi't-Tayyib el-Mütenebbî. Beyrut: Dâru Beyrût, 1403/1983.

Rummânî, Ebü'l-Hasan Ali b. İsa el-Bağdâdî. en-Nüket fi icâzi'l-Kur'an (ㅌelâsu resâil fî icâzi'l-Kur'ân li'r-Rummânî ve'l-Hatțâbî ve Abdülkâhir el-Cürcânî içinde). thk. Muhammed Halefullah - Muhammed Zağlûl Sellâm. Kahire: Dârü'l-Meârif, 1395/1976.

Rûyânî, Ebû Bekr Muhammed b. Harun. Müsnedü'r-Rûyân̂̀ ve bi zeylihi'l-müstedrek mine'n-nuș̂ussi's-sâkıta. thk. Eymen Ali Ebû Yemânî. Kahire: Müessesetu Kurtuba, 1416/1995.

Saîd, Yusuf b. Muhammed. “Dirâse 'akdiyye li bađại'ṣ-ṣıfâtilletî yudde'â ennehâ min bâbi'l-müşâkele". Mecelletu Câmiati'l-İmâm 32 (1421/2000), 15-85.

Seryârî, Zehiyye. Belâğatu'l-Müşâkele ve Delâletuhâ fi'l-Kurâni'l-Kerîm. Tilimsân: Câmi'atu Ebî Bekr Balkâyad, Yüksek Lisans Tezi, 2008.

Sekkâkî, Ebû Yakûb, Yûsuf b. Muhammed. Miftâhu'l-ulûm. thk. Abdulhamîd Hindâvî. Beyrut: Dâru'l-Kütübi'l-'̇lmiyye, 1435/2014.

Siyalkûtî, Abdülhakîm b. Şemsiddîn Muhammed. Hâşiyetü's-Siyalkûtî alâ kitâbi'lMuțavvel. Kum: Menşûrâtü'r-Radî, 1404/1983.

Şevkânî, Ebû Abdillâh Muhammed b. Ali b. Muhammed. Neylü'l-evț̂̂r şerhịi Münteka'lahbâr. Kahire: Mustafa el-Bâbî el-Halebî, ts. 
Tahâvî, Ebû Cafer Ahmed b. Muhammed b. Selâme. Şerhu Müşkili'l-âsar. 16 Cilt. thk. Şuayb el-Arnaût. Beyrut: Müessesetü'r-Risâle, 1415/199.

Taşköprüzade Ahmed Efendi, Ebü'l-Hayr İ̀âmüddîn. Şerhu Fevâidi'l-Ġıyâsiyye min İlmeyi'l-meânî ve'l-beyân. Dersaâdet: Dârü't-Tibâ'ati'l-Âmire, 1312/1895.

Tebrizi, Ebû Zekeriyyâ el-Hatîb Yahyâ b. Ali. Kitâbü'l-kâfî fi'l-arûḍ ve'l-kavâfî. thk. elHassânî Hasan Abdullah. Kahire: Mektebetü'l-Hुancî, 3. Basım, 1415/1994.

Teftâzânî, Sa'düddîn. Şerḥu'l-ḳısmi'ș-sâllis min Miftâhi'l-ulūm lil-Allâma et-Teftâzânî. Cambridge: Houghton Library, Harvard University 1b-221a. https://curiosity.lib.harvard.edu/islamic-heritage-project/catalog/40-990073453990203941 (Erişim 10 Haziran 2021).

Ṭîbî, Şerefüddin Hüseyin b. Muhammed. Fütûhü'l-g்ayb fi'l-keşf an kinâi'r-reyb. thk. İyâd Muhammed Ġavc - Cemil Benî 'Atâ. Dübey: Câizetu Dübey ed-Devliyye li'1-Kur'âni'1-Kerîm, 1434/2013.

Yerinde, Adem. "Belagat İlminde Müşâkele Sanatı". Usul İslam Araştırmaları 30/30 (2018), 7-30.

Yılmaz, Selahattin. Kur'an'da Müşâkele Sanatı. Erzurum: Atatürk Üniversitesi, Sosyal Bilimler Enstitüsü, Yüksek Lisans Tezi, 2012.

Zemahşşî, Ebü'l-Kâsım Cârullah Mahmud b. Ömer. el-Keşşâf an hakâiki ġavâmiḍi'ttenzîl ve uyûni'l-ekâvil fî vucûhi't-tevîl. 4 Cilt. Beyrut: Dârü'l-Kitâbi'l-'Arabî, 3. Basım, 1407/1987. 


\section{Fakhr al-Dīn al-Rāzī in The Conceptualization Process of al-Mushākala (Verbal Similarity)}

\section{(Extended Abstract)}

al-Mushākala, which Arab rhetoricians know very well, is defined rhetorically as stating a word not by its real sound but by the form of another word since the former is accompanied by the latter explicitly (تحقيقا) or implicitly (تقديرا). With the writing of al-Sakkākī's work called Miftāh al- 'ulūm, the Arabic art has been systematically examined, and this art has begun to be commonly known as al-Mushākala. Fakhr al-Dīn al-Rāzī (d. 606/1210), who is located between the period of development of al-Mushākala art and systematization by al-Sakkākī, serves as a bridge in the systematization of this art. al-Rāzī one of the $12^{\text {th }}$ century thinkers, who is known for his works in the field of al-kalām (Islamic theology), philosophy and fiqh (Islamic jurisprudence), wrote a work called Nihāyat al-ījāz fì dirāyat al-i'jāz on the 'ilm al belāgha (science of eloquence) consisting of the sciences of 'ilm al-bayān (the science of clarity of language), 'ilm al-ma 'ānī (the science of meanings) and 'ilm al-badī' (the science of ornamentation). al-Rāzī, who did not include the art of al-Mushākala (lexical simulation), which is defined as stating a word (lafz) by the form of another (word) in that book, but used this art extensively in his tafsīr called Mefātīhu'l-g்ayb. Although he does not examine the al-Mushākala in two parts as explicitly and implicitly, he brings up this art when explaining the verses related to these sections. When explaining the al-Mushākala, al-Rāzī, who usually gives examples of other verses that are related to the subject, does not focus on the literal beauty of this art, but on its close connection with meaning. Although al-Rāzī did not use the name al-Mushākala, while interpreting the verses, he said that Allah's response to the ridicule of the unbelievers (we were

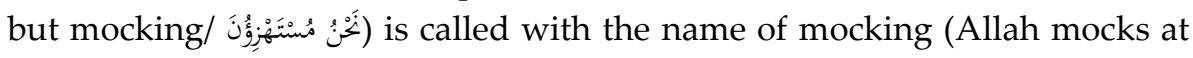
them/الَهُ يَنْنَهْزِئُ this in terms of showing the prevalence of this art. Considering the examples mentioned by al-Rāzī, who gives the art of al-Mushākala with different names, two different approaches to the fact that this art is a metaphor or truth are stand out. According to Ahmad Hindavi Hilal, while al-Rāzī said that alMushākala is a metaphor in many places, he claimed that there is a truth somewhere. Therefore, according to al-Rāzì, it is better to accept this literary art as a metaphor. However, al-Rāzī's different interpretations of the word evil (سَسِ show that he calls the art of al-Mushākala neither a metaphor nor a truth, but the context of the sentence is decisive. As a matter of fact, al-Rāzī considers in verse of "And the recompense of an evil done is a punishment equal to it" 
that the response of evil is evil, that is, that the punishment for evil is bad in relation to an evil person, based on the lexical meaning of the word, as truth. According to al-Rāzì, the important thing is that the word mentioned together in an expression has a different meaning from the first word, it is not whether it is metaphorical, metaphorical or literal. In that case, al-Mushākala is the use of the same word in two different meanings, which includes homonyms. In short, according to al-Rāzī, the first of the two words with al-Mushākala can be truth or metaphor, while the second can be truth or metaphor, provided that it does not have the same meaning as the first. However, since alMushākala was not yet termed in his time, he mentioned this art with different names. In fact, he did not explain in his exegesis of the verses, and referred to another verse mentioned before. Since al-Rāzī's thoughts about alMushākala could not be determined exactly, and his statements were misunderstood, the subject of our study is the extraction of general rule from the small materials that al-Rāzī mentions about the art of al-Mushākala. In this direction, the conceptual framework of the art of al-Mushākala will be included in the introduction of the article. In the first part, the nature of the art of al-Mushākala according to al-Rāzī will be explained, and in the second part, it will be discussed whether this art is a metaphor or a reality for him. 